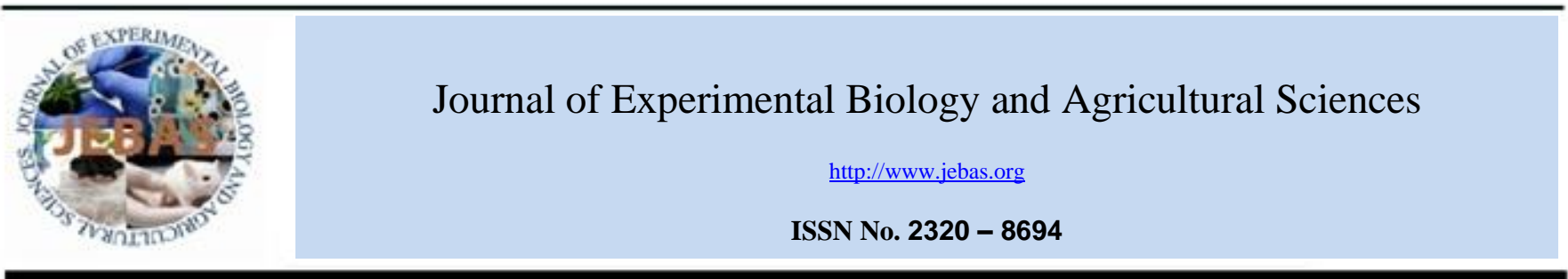

\title{
VEGETATIVE PROPAGATION AND INITIAL GROWTH PERFORMANCE OF Streblus asper LOUR. - A TROPICAL MEDICINAL TREE
}

\author{
MAH Nagalakshmi*, Sahana Vishwanath, KT Prasanna \\ Department of Forestry and Environmental Science, University of Agricultural Sciences, Bengaluru-560065, India \\ Received - March 15, 2018; Revision - May 29, 2018; Accepted - June 16, 2018 \\ Available Online - June 20, 2018
}

DOI: http://dx.doi.org/10.18006/2018.6(3).606.612

KEYWORDS
Streblus asper
Stem cuttings
Rooting ability
IBA treatment
Boric acid

\begin{abstract}
Vegetative propagation of Streblus asper, an important medicinal plant, was studied for efficient rooting using different concentrations of auxins and non auxinic Boric acid. Semi hard wood cuttings of 0.9 $1.2 \mathrm{~cm}$ diameter from mature plants were collected and treated for 24 hours in liquid formulations of 10 ppm, 50 ppm, 100 ppm and 200 ppm concentrations of IBA, IAA, NAA and 50 ppm, 150 ppm, 250 ppm and $350 \mathrm{ppm}$ of Boric acid individually and in combination. Results of the study revealed significant effect $(\mathrm{p}<0.05)$ of IBA and B combination on rooting and survival percentage and found that $10 \mathrm{ppm}$ and $50 \mathrm{ppm}$ IBA with $250 \mathrm{ppm}$ of Boric acid induced highest root number and length and significant steckling capacity with high number of shoots than the other treatments and control. The study explores the scope of clonal propagation of $S$. asper by mature stem cuttings thus providing material for conservation of a selected clone.
\end{abstract}

* Corresponding author

E-mail: mahnagalakshmi@gmail.com (MAH Nagalakshmi)

Peer review under responsibility of Journal of Experimental Biology and Agricultural Sciences.

Production and Hosting by Horizon Publisher India [HPI] (http://www.horizonpublisherindia.in/).

All rights reserved.
All the article published by Journal of Experimental Biology and Agricultural Sciences is licensed under a Creative Commons Attribution-NonCommercial 4.0 International License Based on a work at www.jebas.org.

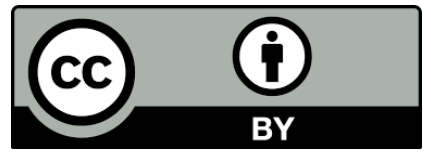




\section{Introduction}

The genus Streblus is one of the fascinating members of the 'Fig' family (Moraceae). It comprises of 25 species and it is geographically distributed mostly in tropical and subtropical Asia. In India it is represented by 5 species, among these 4 species are recorded from North east India while one species Streblus asper is found in drier parts, from Rohilkund, eastwards and southwards to Travancore (Roy et al., 2013). It is commonly known as Siamese rough bush and tooth brush tree (Rastogi et al., 2006). It is a dioecious tree on which flowering occurs between February April and fruiting between May - July. The male flowers are in rounded heads and greenish yellow while female flowers are solitary and greenish (Plate 1A). The ripen fruits are yellowish, sweet flavoured, 1-seeded berry (Singh et al., 2015). Almost every part of $S$. asper is therapeutically used for various curative properties in Indian traditional folk medicine (Afjalus et al., 2013). Verma et al. (2016) reported efficacy of stem bark constituents in curing convulsive and depressive disorders. It is a rich source of cardiac glycosides; Tripathy et al. (2014) isolated twenty cardiac glycosides from the root bark. Glycosides isolated from the root bark possess promising microfilaricidal activity. The seeds are reported to be beneficial in epistaxis and diarrhea; roots in epilepsy and inflammation and stem bark against lymphoderma, chyluria and other manifestations of filariasis (Hashim \& Devi, 2002). The twigs are chewed to make brushes for cleaning teeth and to cure pyorrhea (Sanjay, 2015). Taweechaisupaponng et al. (2014) demonstrated that the ethanol extract of $S$. asper possessed inhibitory effect on subgingival biofilm formation and suggested a potential for developing a natural oral hygiene product against oral infection in people. The one seeded yellowish ripe berries attract avian fugivores which include babuls and Myna (Aruna \& Balasubramanian, 2014). S. asper, being an economic and ecological important species, the propagation of this species through seeds is posing problem as the fruiting season is highly seasonal and thus available for only short period. Besides, the ripen fruits are eaten by avian predators and makes the task of seed collection difficult. Moreover, propagation of the species by seeds is time consuming, troublesome, and hence expensive (Baul et al., 2009). Because of these limitations to seed propagation, vegetative propagation of $S$. asper could increase its utility. There are no known reports in the literature of clonal propagation of $S$. asper. So, the main objective of the present study was to determine whether vegetative propagation by semi hard wood shoot cuttings could be developed as a practical alternative to seed propagation and the experiments were
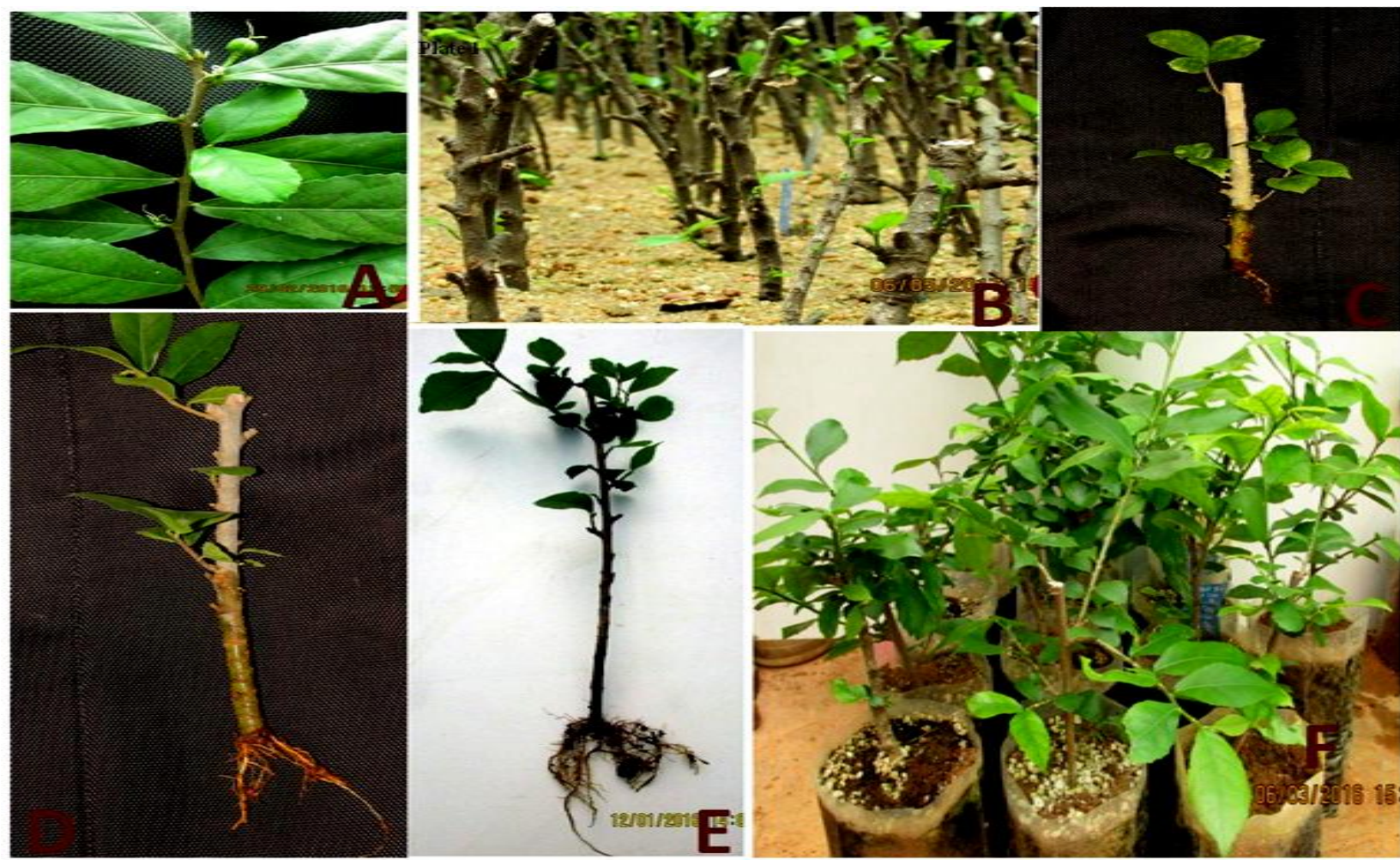

Plat 1 Vegetative propagation and initial growth performance of S.asper (A) Twig with female flower ; (B) Semi hard wood cuttings in sand medium; (C) Rooted cutting in control; (D) Rooted cutting in IBA 50 ppm +250 ppm B; (E) Steckling in IBA 50 ppm +250 ppm B with well developed root system; (F) Stecklings of IBA 50 ppm+250 ppm B in poly bags 
conducted to determine the effect of various auxins and Boron concentrations individually and in combination for the initiation, growth of root formation and initial growth performance.

\section{Materials and Methods}

The experiment was conducted in green house at the Botanical garden of the University of Agricultural Sciences, Gandhi Krishi Vignana Kendra, Bengaluru, India between March and July, 2017 with mean temperature range of $19-35^{\circ} \mathrm{C}$ and relative humidity ranging from $42-90 \%$, depicting typically tropical hot humid climate with 12 hour day and night cycle.

\subsection{Preparation of cuttings and hormone treatment}

Semi hardwood stem cuttings of seven node length and $0.9-1.2$ $\mathrm{cm}$ diameter were obtained from healthy mother tree growing in Indian Institute of Science, Bengaluru (Dhuria, 2007). Before stucking three node length in the sand bed, all the leaves of cuttings were removed to reduce transpiration and cuttings were exposed for $24 \mathrm{hrs}$ to various concentration of Indole-3-butyric acid (IBA), Indole-3-acetic acid (IAA), Naphthalene-3-acetic acid (NAA) in $10 \mathrm{ppm}, 50 \mathrm{ppm}, 100 \mathrm{ppm}$ and $200 \mathrm{ppm}$ and $50 \mathrm{ppm}$, $150 \mathrm{ppm}, 250 \mathrm{ppm}$ and $350 \mathrm{ppm}$ of Boric acid (B). The vertical orientation of the stem cuttings was maintained and spaced adequately to allow sunlight. In the second trial, IBA which was found effective amongst three auxins tested, was combined with effective concentration of B (250 ppm) as suggested by Ono et al. (1999). Control was maintained by dipping the cuttings in distilled water devoid of hormones for 24 hours. Contrary to classic application, cuttings were not exposed to short time high hormone doses, but they were kept in low concentration of hormones for 24 hours. Stock solution of plant hormone of $1000 \mathrm{ppm}$ was prepared by dissolving $100 \mathrm{mg}$ of plant hormones in $0.5 \mathrm{~N} \mathrm{NaOH}$ and made upto $100 \mathrm{ml}$ by distilled water and desired concentration of rooting hormone was made by dilution of the stock.

\subsection{Rooting media and experimental design}

The cuttings were planted in a bed consisting of coarse sand mixed with fine gravel for rooting as it was found to be the best choice for rooting with good drainage and sufficient porosity to allow good aeration (www.itto.int)(Plate 1B). Gehlot et al. (2014) stated that aeration in sand medium plays a very significant role in number of root initiation and as well as on root elongation. Three replications with 10 cuttings per replicate were planted for each treatment and were watered twice daily. A completely randomized design was adopted to study the influence of different treatments on rooting ability of cuttings.

\subsection{Transfer of rooted cuttings}

After 12 weeks of setting the experiment, following the method of Hossain et al. (2018) rooted cuttings treated with IBA and B were transferred into poly bags containing a mixture of sand, soil, cocopeat and perlite in the ratio of $2: 1: 1: 1$ to assess steckling capacity and initial growth performance in the nursery condition.

\subsection{Data collection and statistical analysis}

A cutting was considered to have rooted if it possessed one or more roots measuring not less than $1 \mathrm{~cm}$. Data collected at the end of the rooting period were number of rooted cuttings per treatment, mean number/length of roots per cutting. After a period of 60 days of transplantation in polybags, number of shoots and survival percentage were recorded. Data collected were analysed using Graph pad prism 7. ANOVA and Dunnet's multiple range tests were done to compare means from experimental groups against a control group mean to see the difference in effect.

\section{Results}

\subsection{Percentage of rooting}

The rooting percentage of $S$. asper varied from $6.66 \%$ to $46.66 \%$ under different treatments. In control, rooting was $6.66 \%$ and $93.34 \%$ cuttings remained dormant. Individually significant effect on rooting is shown by IBA $50 \mathrm{ppm}$ followed by IBA $10 \mathrm{ppm}$ and $250 \mathrm{ppm}$ B (Figure 1). IAA was found to be less effective followed by NAA which was totally ineffective at all

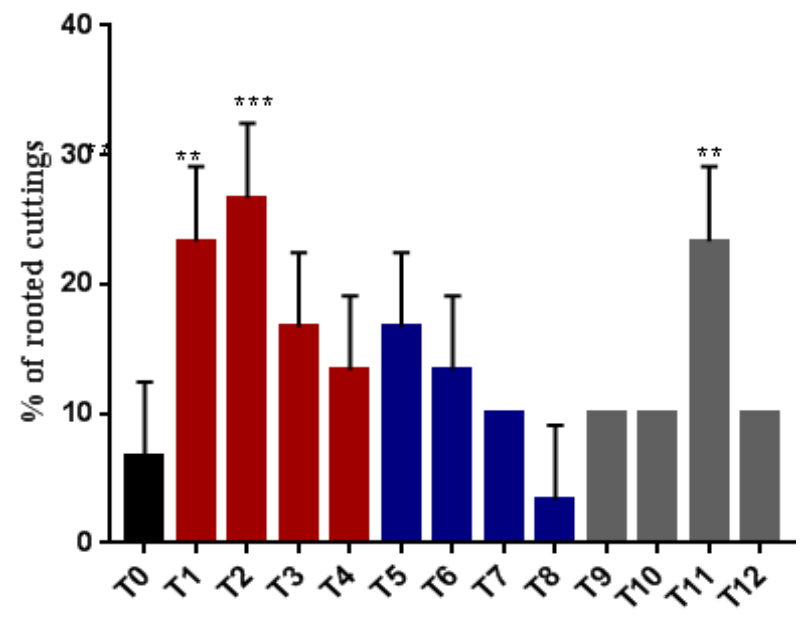

Treatments

Figure 1 Rooting ability of $S$. asper semi hard wood cuttings in different concentrations of IBA, IAA and B. Here TO=control, IBA $(T 1=10 \mathrm{ppm}, T 2=50 \mathrm{ppm}, T 3=100 \mathrm{ppm} T 4=200 \mathrm{ppm}) ; I A A(T 5=10$ ppm, T6=50 ppm, T7=100 ppm, T8=200 ppm); $B(T 9=50 \mathrm{ppm}$, $T 10=150 \mathrm{ppm}, T 11=250 \mathrm{ppm}, T 12=350 \mathrm{ppm}) ; N A A$ not shown in the figure as it was found ineffective.** and *** indicate very significant at $P<0.05$ 
concentrations tested. In combination with B (250 ppm), IBA 50 ppm was found extremely significant followed by IBA 10 $(\mathrm{P}<0.05)$ (Figure 2). Though IBA was effective in inducing root and shoot formation at 10 and $50 \mathrm{ppm}$, only rooting was induced at IBA $100 \mathrm{ppm}$ and $200 \mathrm{ppm}$ without any shoot induction.

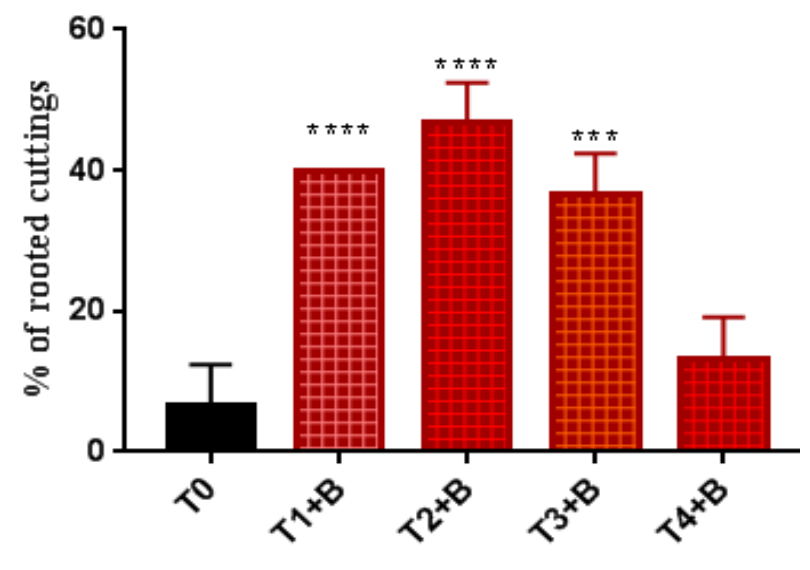

Treatments

Figure 2 Rooting ability of $S$. asper semi hard wood cuttings in different concentrations of IBA with $250 \mathrm{ppm} \mathrm{B}$; here T0=control, IBA (T1=10 ppm, T2=50 ppm, T3=100 ppm T4=200ppm) with 250 ppm B. $* * * *$ and $* * *$ indicate extremely significant and very significant respectively at $\mathrm{P}<0.05$

\subsection{Number of roots of cuttings}

The mean root number of $S$. asper cuttings varied from 0.66 to 9 across the hormone, its concentration and its interaction with B. Root number was lowest in control (Plate 1C) and IBA at $10 \mathrm{ppm}$ and $50 \mathrm{ppm}$ with $250 \mathrm{ppm}$ B (Plate 1D) had significant effect on root number at $\mathrm{P}<0.05$ (Figure $3 \mathrm{a}$ ).

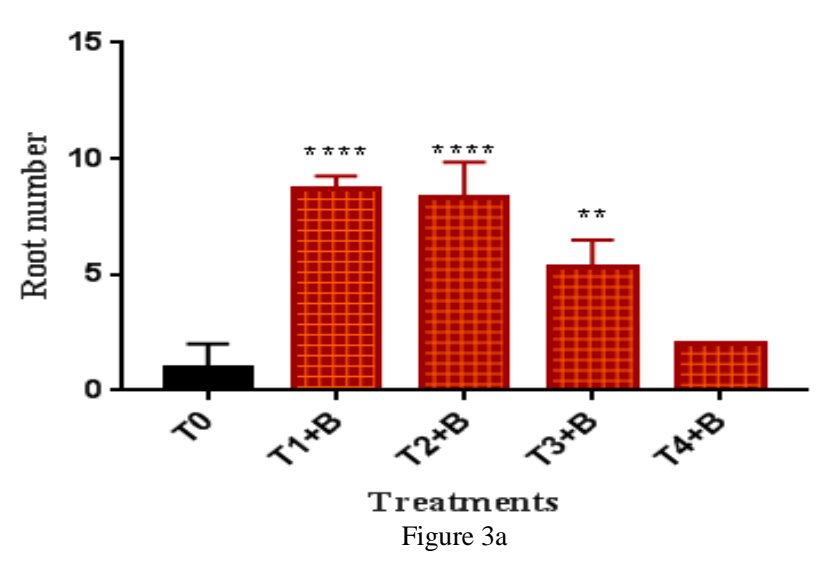

\subsection{Length of roots of cuttings}

The mean root length of $S$. asper cutting was significant at 50 ppm IBA $+\mathrm{B}$ and $10 \mathrm{ppm} \mathrm{IBA}+\mathrm{B}$ combination. The highest mean root length was $3.5 \mathrm{~cm}$ and the lowest was $0.3 \mathrm{~cm}$ with IBA $50 \mathrm{ppm}+\mathrm{B}$ and control respectively (Figure $3 \mathrm{~b}$ ).

\subsection{Shoot number of cuttings}

IBA at $50 \mathrm{ppm}$ and $10 \mathrm{ppm}$ with $250 \mathrm{ppm} \mathrm{B}$ showed significant affect on shoot number and it was followed by IBA $100 \mathrm{ppm}+\mathrm{B}$ (Figure 4a) .

\subsection{Steckling capacity of rooted cuttings}

Survival percentage of $S$. asper cutting was very significantly affected at $10 \mathrm{ppm}, 50 \mathrm{ppm}$ and $100 \mathrm{ppm}$ of IBA combined with 250 ppm B (Plate 1E \& 1F; Figure 4b).

\section{Discussion}

The usefulness of auxins as a rooting aid during vegetative propagation has been summarized by many researchers (Ahmed et al., 2003 Abdullah et al., 2006; Sanjose et al., 2012). In Moraceae, auxin treatments were carried out in order to facilitate the rooting at different concentrations of IBA and found effective in rooting of Ficus and Morus species which include F. glomerata L. (Bhatt \& Badoni, 1993), F. Hawaii (Siddiqui \& Hussain, 2007), $M$. nigra (Kalyoncu et al., 2009) F. racemosa, F. microcarpa F.religiosa, F. benghalensis (Mathew et al., 2011), M. alba (Singh et al., 2014) and F. carica (Kaur \& Kaur, 2017). Abdullah et al. (2005) reported rooting in few timber trees viz., Sweitenia macrophylla, Platanus acerifolia, Artocarpus heterophylla by

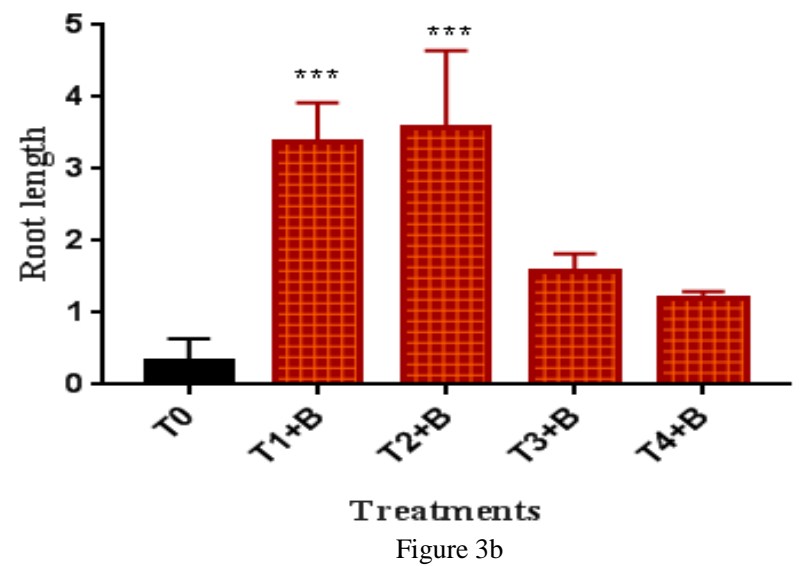

Figure 3 (a) Root number (b) Average length of root per cutting of $S$. asper in different concentrations of IBA with 250 ppm B; here T0=control, IBA $(\mathrm{T} 1=10 \mathrm{ppm}, \mathrm{T} 2=50 \mathrm{ppm}, \mathrm{T} 3=100 \mathrm{ppm}, \mathrm{T} 4=200 \mathrm{ppm})$ with $250 \mathrm{ppm} \mathrm{B}$. $* * * *$ indicate extremely signifiscant and $* * * * *$ very significant at $\mathrm{P}<0.05$ 


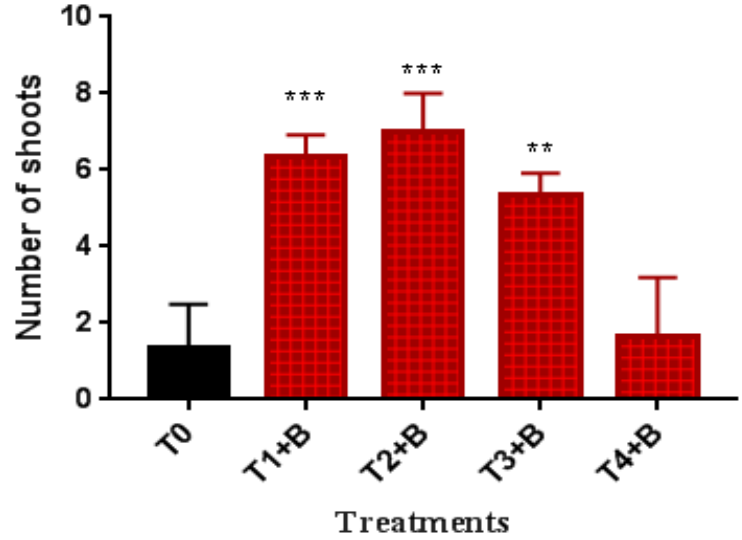

Figure 4a

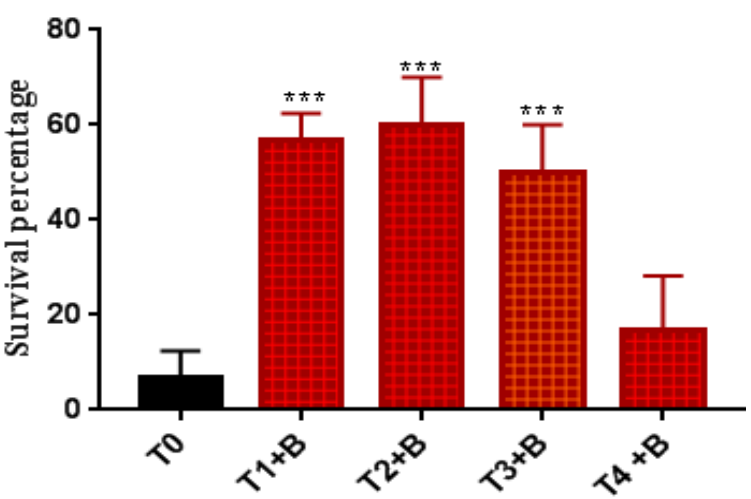

Treatments

Figure $4 \mathrm{~b}$

Figure 4 (a) Number of shoots (b) Survival percentage of cuttings of S. asper 60 days after transplanting using different concentrations of IBA with B; here $T 0=$ control, $I B A(T 1=10 \mathrm{ppm}, T 2=50 \mathrm{ppm}, T 3=100 \mathrm{ppm}, T 4=200 \mathrm{ppm})$ with $250 \mathrm{ppm} \mathrm{B.} * *$ and $* * *$ indicate very significant at $P<0.05$

mature stem cuttings by using IBA. IBA is found to be more advantageous than other auxins, being non toxic in a wide range of concentrations without easily getting degraded with longer permanence in the application site (Ono et al., 1999). The application of IBA on rooting percentage of semi hard wood cuttings of mature $S$. asper had similar effect resulting in significant number of robust and lengthy roots. Biochemically, induction of root using IBA was found due to activation of polysaccharide hydrolysis resulting in the increase of content of physiologically active sugar providing materials and energy for meristematic tissue and later for root primordia and roots (Abdullah et al., 2005). Besides, the use of water as a liquid carrier of IBA might be advantageous in the present study as reported by Ezekiel (2010) who stated that the preparation of liquid formulation of IBA dissolved in water is more effective for rooting most plants than IBA dissolved in alcohol as high concentration of alcohol may dehydrate and become toxic and injure the basal stems.

The occurrence of meagre rooting in non treated cuttings in $S$. asper is in conformity with rooting response of leaf less cuttings of matured stock plants of Albizia zygia, Blighia welwitschii (Egbe et al., 2012). The decline in ease of adventitious root formation of mature tree cuttings is may be due to physiological age of the stock plants integrated with several progressive changes in morphological, anatomical and biochemical traits such as decreased sensitivity of aging tissue to rooting promoters and/or accumulation of inhibitory substances which inhibit rooting and decreased content of endogenous auxins as stated by Ezekiel (2010). Exogenous application of IBA was found to result in root forming process in cuttings of S. asper to a maximum of $26 \%$ and was further enhanced by the addition of B (250 ppm) to $46 \%$ as stated by Abdullah et al., (2005) that though initiation of root primordial requires auxin but for subsequent primordial development both auxin and non auxin components are needed. Boric acid have a direct control on the carbohydrate movement by the formation of ionizable complex boron- sacarose, thus facilitating the quick carbohydrate transport through the membrane to the places where cellular development and elongation occur (Ono et al., 1999; Stefanini et al., 2004). According to Esau (1965), boron plays a primary role activating the meristematic cells during the endogenous formation of root from pericycle or the endoderm. The effectiveness of boron with low concentration of IBA was supported by Ono et al, (1999) who stated that with B, IBA behaved effectively at low concentration.

The contrasting effects of increasing IBA concentration inducing only roots without sprout induction may reflect differential effects of applied auxin on the process of root initiation and development as the different concentrations of IBA applied gives rise to varied rooting response in different species. The highest survival $(60 \%)$ in $S$. asper cuttings was observed when treated with $50 \mathrm{ppm}$ IBA+B followed by $10 \mathrm{ppm}$ IBA+B (50\%) as observed in Baccaurea sapida cuttings (Nath \& Barooah, 1992). The ANOVA and DMRT at $\mathrm{P}<0.05$ showed that all the rooting parameters which include rooting percent, root number and root length per cutting and steckling capability with well developed shoot were dependant on lower concentration of IBA and the presence of B at $250 \mathrm{ppm}$.

\section{Conclusion}

The male and female trees of $S$. asper cannot be detected before flowering of plants which takes 4-5 years of planting. Multiplication through mature stem cuttings from identified male and female matured stock plant can be an important tool for 
resolving the problem of female tree identification. In the present study, rooting of $S$. asper semi hard wood cutting was successfully achieved by the application of IBA and B (50 ppm $+250 \mathrm{ppm}$ respectively) and resulted in $60 \%$ steckling capacity. This protocol may be used in nurseries for its easy and faster multiplication. However, further experimentation with regard to the type of cutting, time of cutting and field trials of the rooted cuttings of the species for large scale clonal multiplication could be an important aspect of future study. The production of vigorous and healthy stecklings by vegetative means would enhance forest management through enrichment planting especially for dioecious species where male and more female trees with poor recruitment rates from seeds are to be planted together.

\section{Acknowledgement}

The author would like to acknowledge University Grants commission for the financial assistance to this research work under the sanction no. F.15-1/2016-17/PDFWM-2015-17-KAR34814 (SA-II) dated 11/04/2016. The staff of department of Forestry and Environmental Science and Mahatma Gandhi Botanical Garden, University of Agricultural Sciences, Bengaluru are acknowledged for their support during the research work.

\section{Conflict of Interest}

The authors declare that there is no conflict of interest regarding the publication of this research paper.

\section{References}

Abdullah ATM, Hossain MA, Bhuiyan MK (2005) Propagation of Latkan (Baccaurea sapinda Muell.Arg) by mature stem cutting. Research Journal of Agriculture and Biological Sciences 1: 129143.

Abdullah ATM, Hossain MA, Bhuiyan MK (2006) Clonal propagation of guava (Psidium guajava Linn.) by stem cuttings from mature stock plants. Journal of Forestry Research 17: 301304.

Ahmed MS, Abbasi NA, Amer M (2003) Effect of IBA on hard cuttings of Peach root stocks under green house conditions. Asian Journal of Plant Science 2: 265-269.

Afjalus SM, Salahuddin M, Rahman M, Khatun A, Yasmin F (2013) Investigation of Analgesic and antioxidant activity of ethanolic extract of Streblus asper Lour. (Moraceae) leaf and bark. International Research Journal of Pharmacy 4: 262-266.

Aruna R, Balasubramanian P (2014) Fruiting phenology and avian frugivory of Streblus asper Lour. in a mixed dry deciduous forest,
Western ghats, India. International letters of Natural Sciences 17 : 16-21.

Baul TK, Mezbahuddin M, MOhiuddin M (2009) Vegetative propagation and initial growth performance of Stereospermum suaveolens DC., a wild tropical tree species of medicinal value. New forests 37: 275-283

Bhatt BP, Badoni AK (1993) Studies on vegetative propagation in Ficus Glomerata L. moraceae stem cuttings. Indian Forester 119: 247- 251.

Dhuria SS (2007) Nursery Technology: Vegetative propagation of forestry species for higher biomass production. Journal of Tropical Forestry 23: 136-140.

Egbe EA, Chuyong GB, Fonge AB, Tata BL, Tabot PT (2012) The effect of different concentrations of indole 3 butyric acid (IBA) on leafy stem cuttings of four tropical timber species. Journal of Horticulture and Forestry 4: 85-91.

Esau K (1965) Plant anatomy. John Willey and Sons, New York.

Ezekiel A (2010) Viable option and factors in consideration for low cost vegetative propagation of tropical trees. International Journal of Botany 6: 187-193.

Gehlot A, Arya S, Arya ID (2014) Vegetative propagation of Azadirachta indica A.Juss (Neem) through cuttings: A review. Nativa, Sinop 2: 139-146.

Hashim MS, Devi KS (2002) Insecticidal action of the polyphenolic rich fractions from the stem bark of $S$. asper on Dysdercus cingulatus. Fitoterapia 74: 670-676.

Hossain MA, Kumar SM, Seca G, Maheran AA, Noraini AS (2018) Mass propagation of Dendrocalamus asper by branch cutting. Journal of Tropical Forest Science 30: 82-83.

Kalyoncu IH, Ersoy N, Yilmaz M, Aydin M (2009) Effects of humidity level and IBA dose application on the soft wood top cuttings of white mulberry (Morus alba L.) and black mulberry (Morus nigra L.) types. African Journal of Biotechnology 8: 3754-3760.

Kaur A, Kaur A (2017) Effect of IBA concentration on success of cuttings of Fig CV. Brown Turkey. International Journal of Recent Scientific Research 8: 21576-21579.

Mathew G, Skaria BP, Joseph A (2011) Standardization of conventional propagation techniques for four medicinal species of genus Ficus Linn. Indian journal of Natural products and Resources 2: 88-96. 
Nath JC, Barooah S (1992) Propagation of some minor fruits by rooting of stem cuttings. Horticultural Journal 5: 109-113.

Ono EO, Rodrigues JD, Pinho SZ (2000) Studies on stem cuttings of Kiwi (Actinidia chinensis Pl. CV Bruno). Brazilian Archives of Biology and Technology 43: 117-125

Roy DK, Samiran Panday, Sinha BK, Sawmliana M (2013) Taxanomic note on Streblus Lour.(Moraceae) in Northeast India. NeBio 4: 50-54.

Rastogi S, Kulshreshtha DK, Rawat AKS (2006) Streblus asper Lour. (Shakhotaka): A review of its chemical, pharmacological and Ethnomedicinal properties. Evidence Based Complement Alternate Medicine 3: 217-222.

Sanjay P (2015) A review on chemical and pharmacological profiles of Shakhotaka (Streblus asper Lour .) Anveshana Ayurvedic medical journal 1: 256-262

Sanjose MC, Romero L , Janeiro LV (2012) Effect of indole 3butyric acid on root formation in Alnus glutinosa microcuttings. Silva Fennica 46: 643-654

Siddiqui MI, Hussain SA (2007) Effect of Indole butyric acid and types of cutting on root initiation of Ficus Hawaii. Sarhad Journal Agriculture 23: 921-926.
Singh KK, Choudhary T, Kumar A (2014) Effect of various concentrations of IBA and NAA on the rooting of stem cuttings of Mulberry (Morus alba L.) under the mist house condition in Garhwal Hill region. Indian Journal of Hill Farming 27: 125-131.

Singh SP, Singh AP, Singh R, Rai PK, Tripathi AK, Kumar NK (2015) A brief study on Streblus asper L.-A review. Research Journal of Phytomedicine 1: 65-71 2.

Stefanini MP, Ming LC, Uesugi G, Figueiredo R (2004) Influence of IBA and boric acid on rooting of stem cuttings of Aloysia triphylla (L' Herit ) Britton. Acta horticulturae 629: 329-332.

Taweechaisupaponng S, Pinsuwan W, Suwannarong W, Kukhetpitakwong R, Luengpailin S (2014) Effects of Streblus asper leaf extract on the biofilm formation of subgingival pathogen. South African Journal of Botany 94: 1-5.

Tripathi AK, Tripathy S, Verma NK (2014) A study on pharmacognostic and chemomicroscopic features of Streblus asper L. Der Pharmacia Lettre 6: 30-36

Verma V, Avinash C, Tripathi, Saraf SK (2016) Bio active non sterol tritrepenoid from Streblus asper : microwave assisted extraction, HPTLC profiling, computational studies and neuropharmacological evaluation in BALB/c mice. Pharmaceutical Biology 54: 2454 -2464.

www.itto.int 